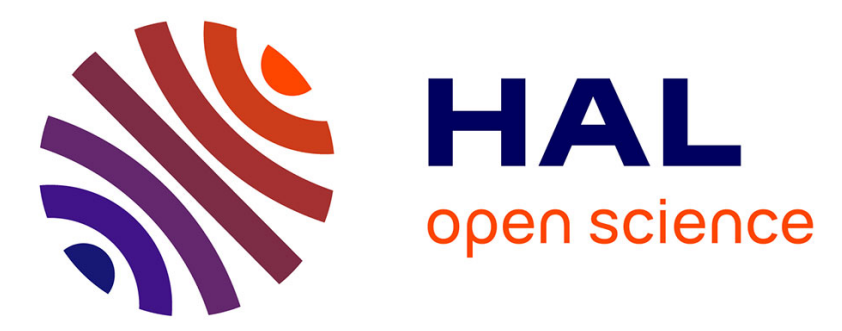

\title{
Species of Hollinella (Palaeocopida: Ostracoda: Crustacea) as stratigraphical indices of the Late Permian-Early Triassic post-extinction interval
}

Sylvie Crasquin, Marie-Béatrice Forel, Aihua Yuan, Galina Nestell, Merlynd Nestell

\section{To cite this version:}

Sylvie Crasquin, Marie-Béatrice Forel, Aihua Yuan, Galina Nestell, Merlynd Nestell. Species of Hollinella (Palaeocopida: Ostracoda: Crustacea) as stratigraphical indices of the Late PermianEarly Triassic post-extinction interval. Journal of Systematic Palaeontology, 2017, 16 (3), pp.213-224. 10.1080/14772019.2017.1283648 . hal-02052760

\section{HAL Id: hal-02052760 https://hal.sorbonne-universite.fr/hal-02052760}

Submitted on 28 Feb 2019

HAL is a multi-disciplinary open access archive for the deposit and dissemination of scientific research documents, whether they are published or not. The documents may come from teaching and research institutions in France or abroad, or from public or private research centers.
L'archive ouverte pluridisciplinaire HAL, est destinée au dépôt et à la diffusion de documents scientifiques de niveau recherche, publiés ou non, émanant des établissements d'enseignement et de recherche français ou étrangers, des laboratoires publics ou privés. 
Species of Hollinella (Palaeocopida, Ostracoda, Crustacea) as stratigraphic indices of the Late Permian - Early Triassic post extinction interval (1)

8

8
Arlington, TX 76019, USA

Sylvie Crasquin ${ }^{a}$, Marie-Béatrice Forel ${ }^{a}$, Yuan Aihua ${ }^{b}$, Galina Nestell ${ }^{c}$ Merlynd Nestell

${ }^{\mathrm{b}}$ China University of Geosciences, Wuhan, P.R. China

c Department of Earth and Environmental Sciences, University of Texas at Arlington,

\section{Abstract}

Members of the Ostracoda Order Palaeocopida, except for two very rare genera (Puncia and Manawa), disappeared in the stratigraphic record close to the Permian - Triassic boundary (PTB) event. Species of the genus Hollinella are often present just after the end Palaeozoic mass extinction event, in the latest Permian and earliest Triassic beds. They are one of the latest representatives of the Palaeocopida, the typical Palaeozoic straight dorsal border ostracods. The Early Triassic species are assigned by most authors to Hollinella tingi (Patte, 1935), but this assignment is incorrect. This species is present in the latest Permian and the earliest Triassic, and therefore is considered as a biostratigraphic index fossil of the postmass extinction interval. A revision of the Hollinella species from this interval is presented herein. Three Hollinella species occur in the earliest Triassic and are assigned to Hollinella panxiensis Wang 1978, Hollinella magninoda Wang 1978 and Hollinella (Hollinella) lungcamensis sp. nov. This new species of the post-PTB event and present in strata exposed in the northern part of Vietnam is described. These three species cross the PTB and $H$. $(H$. lungcamensis is characteristic for the post extinction period (latest Changhsingian - earliest Induan).

Keywords: Permian - Triassic extinction event; ostracods; Palaeocopida; biostratigraphic index.

\section{Introduction}


Specimens of the genus Hollinella Coryell, 1928 (Palaeocopida, Ostracoda, Crustacea) are present in many sections of the Permian - Triassic boundary interval. Although the preservation is quite always very poor, these occurrences are remarkable because this genus is one of the latest representatives of the Palaeocopida, an emblematic Palaeozoic straight dorsal border ostracod group which disappears after the Permian - Triassic boundary event (PTBE). Three extremely rare genera, Promanawa, Puncia and Manawa, assigned to the Palaeocopida (Superfamily Puncioidea; Horne et al. 2002) are still extant in the Southern Pacific area (e.g., Hornibrook 1949, 1963). Some authors, however, consider that there are no living members of the Palaeocopida (see Martin \& Davis 2001, p. 29-30). Except these three genera, the last well-dated Palaeocopida are known from the Early Anisian (genus Triassicindivisia; Forel \& Crasquin 2011, Crasquin \& Forel 2013).

Among the residual Early Triassic Palaeocopida (Crasquin-Soleau et al. 2004), only one species is supposed to cross the PTBE and it is assigned to Hollinella tingi (Patte, 1935). H. tingi was described in 1935 by Patte from the Early Permian of South China, but it is not the species which occurs in the earliest Triassic. All specimens discovered in the earliest Triassic, which are quite often preserved as moulds, were assigned to $H$. tingi by nonspecialists, and this error was repeated many times. The aim of this paper is to clarify a very confused situation.

A new species, Hollinella (H.) lungcamensis sp. nov., is described from the post-PTBE of Northern Vietnam.

\section{Original description of Hollinella tingi (Patte, 1935)}

It is important to note that the genus Hollinella frequently shows significant intraspecific variability. Sexual dimorphism is apparent from different adventral structures (for example, a large and striated velum in females, which is absent or replaced by a small nodule row in males) and the stronger anteroventral convexity of the female carapace - corresponding to the brood pouch. The carapace shape of Hollinella shows also strong ontogenetic variations. Such variability is also recorded from many other palaeocopid taxa (for example, Sohn 1950 for Kirkbyidae and Miltonellidae; Bless \& Jordan 1972 for Hollinellidae; Watabe \& Kaesler 2004 for Paraparchitidae).

According to the revision of the Hollinellidae by Bless \& Jordan (1972), Hollinella tingi 
is very poorly known. The species was originally described as Beyrichia tingi in 1935 by Patte from the Early Permian T'ungstzu and Takuhesinch'ang Districts of South China. No holotype was designated by Patte (1935). The preservation of this material is poor and its description was based on external moulds only. The original description in French is reproduced in the annexe.

The species was published once more by Hou (1954). Its description was written in Chinese and in English. The English version is not the exact translation of the Chinese one. Note that in Hou's description and in the translation below, the orientation of the carapace is reversed, and males and females are confused. The English translation made by the third author of the present paper is given in the annex.

Hou (1954) figured the "holotype" (Hou 1954: pl. 1, fig. 2a). It is not clear if her "holotype" is the original and the true one, or if it is a lectotype. Hou found this species in Early Permian black shale of the Chihsia Formation (Western Hubei, South China).

In 1964, Ishizaki assigned specimens discovered in the Early Pennsylvanian (Late Carboniferous) of Japan to Hollinella tingi. The preservation of the figured specimen (Ishizaki 1964: pl. 1, fig. 1) is so poor that it is impossible to confirm its assignment. The stratigraphic range in the Early Pennsylvanian is therefore questionable.

\section{"Hollinella tingi" and the PTBE}

In studies of Permian-Triassic ostracods, specimens of Hollinella are frequently reported from the latest Permian and the earliest Triassic. In most of these papers, the specimens of Hollinella are assigned to H. tingi. As explained in Crasquin-Soleau et al. (2004), all these specific assignments are incorrect. The first erroneous determination was made by Wang (1978), and thereafter repeated again and again by other authors.

In 1978, Wang figured and described four Hollinella species from the Late Changhsingian and Early Induan of Western Guizhou and North-Eastern Yunnan: H. tingi (Wang 1978: pl. 1, figs 5-7), and three new species including H. magninoda (Wang 1978: pl. 1, fig. 11), H. panxiensis (Wang 1978: pl. 1, figs 1-4, and H. capacilacuna (Wang 1978: pl. 1, figs 8-10). English translations are absent from Wang's paper. We made these translations and give them in the annexe (some passages are unclear in the original descriptions. Our translation is literal and without interpretation). With regard to these "descriptions" and the illustrations (Wang 1978), we suggest that: Hollinella capacilacuna and H. magninodosa are 
valid species and are Late Permian in age.

For the present authors, the specimens assigned to $H$. tingi and specimens assigned to H. panxiensis belong to the same species, H. panxiensis, which has no long posterodorsal spine, but just a small lateral flattening (pinch) of the posterior cardinal angle (Wang 1978: pl. 1 , figs 1-4). $L_{3}$ is elongated antero-posteriorly. When the velum is completely developed, it extends from the anterior cardinal angle to the posterior cardinal angle. Some small nodules could be present on the upper part of $L_{3}$. The specimen illustrated by Wang (1978) on pl. 1, fig. 6 differs slightly by its higher height/length ratio possibly due to ontogeny and could be determined as H. panxiensis?

In 1981, Wei illustrated three specimens from the Induan - Olenekian interval of Sichuan (Wei 1981: pl. 1, figs 1-3), and assigned them to Hollinella tingi. The first two specimens (Wei 1981: pl. 1, figs 1 and 2) are very poorly preserved and the assignment appears dubious. The specimen figured on pl. 1, fig. 3 (ibid.) is not a Hollinella, but a Kloedenellid species.

In 1985, Kozur illustrated a specimen of Hollinella tingi (pl. 13, fig. 3) from the Werfenian (Induan) of the Bükk Mountains (Hungary). It is impossible to determine this corroded and abraded specimen at the specific level. In any case, it is not $H$. tingi. Furthermore, it is not reasonable to use this specific determination as a stratigraphic index for the Permian - Triassic boundary as suggested by Kozur (1985).

In 1987, Shi \& Chen illustrated specimens assigned to $H$. tingi (pl. 16, figs 2-5) from the early and middle Changhsingian of the Meishan section but gave no description. The specimen figured on pl. 16, fig. 2, is close to H. panxiensis; it apparently shows cardinal pinches, but the carapace is quite longer. The three other specimens (Shi \& Chen 1987: pl. 16, figs 3-5) are poorly preserved and/or broken, but the three lobes are distinct and ornamentation could be observed on $\mathrm{L}_{3}$ (fig. 3). Shi \& Chen (1987) studied all Changhsingian ostracods of the Meishan section and did not report the species from the upper part of the section. We consider that these specimens belong to $H$. panxiensis.

Hao (1992a, b, 1993, 1994 and 1996) illustrated specimens of Hollinella, including $H$. tingi, from the Late Permian and/or the Induan of Guizhou.

In 1992a, Hao presented eleven ostracod species from the Early Triassic, including three species of Hollinella: Hollinella cf. H. plana Jiang 1983 (p. 39, pl. 1, fig. 1) is not a species of Hollinella, but a Kloedenelid ostracod; Hollinella unispinata (a new species characterized by 
long spines at cardinal angles; p.39, pl. 1, fig. 2-3) is a synonym with Hollinella magninoda Wang, 1978). The specimens assigned to $H$. tingi (p. 39, pl. 1, figs 5-6) do not belong to that species. The first one has a very different lateral outline and is very badly preserved (pl. 1, fig. 5) and the second one (pl. 1, fig. 6) shows a strong reticulation in front of $L_{1}$ and seems to have a ventral ridge. We assign it to $H$. panxiensis based on the presence of the pinch at the cardinal angles. The specimen of "H. tingi" illustrated in Hao (1992b; pl. 1, fig.1) from the Changhsingian of Guizhou could be conspecific with $\mathrm{H}$. panxiensis due to its complete velum extending along the entire free margins. In a paper on the Changhsingian from Guizhou, Hao (1993) assigned two specimens to H. tingi (Hao 1993: pl. 1, figs 1-2). The illustration is of poor quality and there is no description. As can be seen on plate 1 of Hao (1993), the cardinal pinches are indistinct, but the specimens show an elongated antero-posteriorly $L_{3}$ like the specimens of Wang (1978). Furthermore, the velum begins at the anterior cardinal angle and ends at the posterior cardinal angle. We consider that these specimens could belong to $H$. panxiensis. In the same paper, Hao described a new species: H. echinata. The three illustrated specimens are quite small ( $\mathrm{L}: 0.81-0.83 \mathrm{~mm})$. The description is a summary and very general. The author just mentioned that the "border" of $H$. echinata possesses many short spines. In his publications from 1994 and 1996, Hao illustrated ostracods from the Permian - Triassic interval in Guizhou Province, but pictures of Hollinella are identical to those in the publications from 1992a and 1992b.

Forel \& Crasquin (2011) illustrated four species of Hollinella from the Griesbachian (Early Triassic) of the Meishan PTB GSSP's section: H. cf. H. martensiformis, H. cf. H. panxiensis, H. sp. 1, and H. sp. 2.

- $\quad$ H. cf. H. martensiformis is a species similar to the Late Permian H. martensiformis of the same section (Crasquin et al. 2010), characterized by its long and straight dorsal border with accurate cardinal angles, tubercles on the upper part of $L_{3}$ and a row of tubercles along the ventral margin. It is also very close to the species from Vietnam (see below).

- $\quad H$. cf panxiensis: The specimens are quite poorly preserved and could belong to $H$. panxiensis.

- $\quad$ H. sp.1 and H. sp.2 are so badly preserved that a specific assignment is impossible. In a study on the Late Permian - Early Triassic boundary interval of North Iran (Elikah Valley section, Central Albourz; Forel et al. 2015), some Late Permian Hollinella have been illustrated as $H$. sp. $1, H$. sp. 2 and $H$. sp. 4, and two Early Triassic species as H. sp.3 and Hollinellidae? 
indet. All the material is poorly preserved and does not allow a more precise determination. Two tables are proposed in the annexe to summarize the distributions of all the listed species and the systematic attributions considered valid in this paper.

\section{Hollinella species from the Permian - Triassic boundary in Vietnam}

New material has been discovered in the latest Permian - Early Triassic boundary interval of the Hong Ngai Formation at the Lung Cam section, Northern Vietnam. In the Late Permian-Early Triassic this area belonged to the southern margin of the South China Craton and was a shallow marine carbonate platform (Son et al. 2007). The Lung Cam section was recently resampled and analysed in detail (Nestell et al. 2015; Wardlaw et al. 2015). More than 200 specimens of Hollinella, associated with numerous other ostracod species (work in progress) were found in residues of 12 conodont samples (from VN 15 up to VN28) located above the extinction event and around the PTB (fig. 1).

This rich material is quite well preserved and permits a detailed study of a new species of Hollinella which is characteristic of the post-extinction event. The assemblage shows a high morphological diversity including all the transitional forms between the extremes (Figs 2 and 5). Herein, 201 specimens were measured ( $\mathrm{H}$ and $\mathrm{L}$ include here the adventral structure; fig. 3). The length (L) ranges between 426 and $1130 \mu \mathrm{m}$ and the height $(\mathrm{H})$ between 282 and $807 \mu \mathrm{m}$. Specimens of all this size range evenly occur in all the 12 samples.

Hollinella (H.) lungcamensis sp. nov. (see description below) shows different morphotypes. A first group has free margins ornamented by several rows of spines (see figs. $2,4,5)$ from anterior cardinal angle (ACA) to the posterior cardinal angle (PCA). The second group has a well-developed velum which is completely calcified forming a continuous blade from the ACA to the posteroventral part of the carapace. The posterior part of the carapace is ornamented by spines. All transitional forms between these two extremes are represented. If we plot the size of specimens with spines and specimens with a complete velum on an $\mathrm{H} / \mathrm{L}$ diagram (fig. 4), it becomes clear that this morphological variability is due to ontogenesis.

\section{Sexual dimorphism and ontogenetic variability in the Palaeocopida}

Sexual dimorphism and ontogenetic variability in palaeocopids (Van Veen 1922; 
Jaanusson 1957; Henningsmoen 1965; Kesling 1969) and particularly in the Hollinellidae (see example on fig. 6) (Jaanusson 1957; Henningsmoen 1965; Bless \& Jordan 1970, 1972) has been known for a long time.

The shape of the carapace changes during each moult. Some features develop gradually during the ontogeny whereas others appear suddenly at the transition to the adult stage. Five to six stages of growth, including the adult, are recorded for Hollinella. In the genus Hollinella the ventral lobe is further developed than $L_{2}$ and $L_{3}$ during early ontogeny, whereas $L_{2}$ and $L_{3}$ become more prominent in the latest juvenile stages. Early instars are often completely smooth, whereas latest ones become granulose. In the Carboniferous species, which show a tubulous layer during maturity, the last immature stage may possess a completely developed velum. Antero- and/or posterodorsal spines occur frequently in juvenile stages of Hollinella. They may or may not persist until maturity (Bless \& Jordan 1972). Sexual dimorphism usually appears in the adult stage, but some pre-adult dimorphism has been described from the last or two last juvenile stages (Bless 1970; Bless et al. 1969; Forel et al. 2015 and references included). Such pre-adult dimorphism applies to the lobation, and the size and shape of the adventral structures. In the "true dimorphic" genera, for example of the Hollinidae family (Bless \& Jordan 1971, 1972), the tecnomorph specimens keep the same morphology during ontogeny and the heteromorphs develop different adventral structures. In the "trimorphic" genera (Bless \& Jordan 1972), juveniles are clearly morphologically different due to the partial absence of secretion of calcite prims in juveniles, so that the velum is not formed. According to Bless \& Jordan (1972), presumed heteromorphs differ from presumed adult tecnomorphs by the following characters: in heteromorphs $L_{3}$ is larger than the domicilium (part of the carapace exclusive of projecting velate structure) and the velum width is smaller than the domicilium. The space between the right and left velums, the antrum, can be ornamented in heteromorphs and smooth in tecnomorphs.

Herein, the ontogenetic variability is expressed by the progressive calcification of the spines forming a continuous velum with all the transitional forms in between during the ontogeny. Sexual dimorphism is sometimes observable at some of the largest specimens. Some males show a greater height and some females are more elongated with the maximum of height in the posterior part. But it is difficult to assign gender for a great majority of the adult specimens. 


\section{Repository}

All the specimens are deposited in the collections of Pierre et Marie Curie University, Paris, France, under the prefix P6M.

\section{Systematics}

\section{Abbreviations (fig. 7)}

$\mathrm{AB}$ : anterior border, $\mathrm{PB}$ : posterior border; $\mathrm{DB}$ : dorsal border; VB: ventral border ACA: anterior cardinal angle; PCA: posterior cardinal angle

$\mathrm{S}_{1}, \mathrm{~S}_{2}, \mathrm{~S}_{3}$ : sulcus from anterior to posterior

$L_{1}, L_{2}, L_{3}, L_{4}$ : lobes from anterior to posterior

L: maximum length of carapace; $\mathrm{H}$ : maximum height of carapace; $\mathrm{W}$ : maximum width of carapace

Class Ostracoda Latreille, 1806

Subclass Podocopa Sars, 1866

Order Palaeocopida Henningsmoen, 1953

Suborder Beyrichicopina Scott, 1961

Superfamily Hollinoidea Swartz, 1936

Family Hollinellidae Bless \& Jordan, 1971

Genus Hollinella Coryell, 1928 emend. Kellett, 1929

Subgenus Hollinella (Hollinella) Coryell, 1928

Hollinella (Hollinella) lungcamensis Crasquin, sp. nov.

(Figs 3-5)

Diagnosis. A species of Hollinella (Hollinella) with clearly expressed lobation ( $\mathrm{L}_{1}$ to $\left.\mathrm{L}_{4}\right)$ but without ventral lobe; spines along free margin and on lobes; ontogenetic variability of velar structures: spines at free margins are replaced by continuous velum which joins ACA and posteroventral part of the carapace; sexual dimorphism expressed by thickening of posterior part of the carapace.

Derivation of name. After Lung Cam section, Northern Vietnam (type locality).

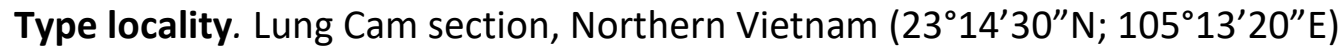


Type level. Sample VN20, Hong Ngai Formation, latest Changhsingian, latest Permian.

Material. Holotype: P6M3775, right valve (fig. 5C), sample VN20. Paratypes: P6M3776, left valve (fig. 5A), sample VN20; P6M3777, left valve (fig. 5E), sample VN25. Additional material: 201 complete valves and carapaces, many fragments.

Occurrences. samples VN15, VN18, VN19, VN20, VN21, VN22, VN23, VN24, VN25, VN26, VN27, VN28, Lung Cam section (fig. 1), Northern Vietnam, Hong Ngai Formation, latest Changhsingian (latest Permian) - Griesbachian (parvus zone), earliest Triassic.

Description. Species of Hollinella (Hollinella) with long straight DB (68-80\% of total L) and clear morphological variations between dimorphs occurring early in ontogenesis.

ACA very obtuse $\left(130-140^{\circ}\right)$; lobation well developed: $L_{1}$ quite always visible, anterior part is smoothed out, top of $L_{1}$ located at anterior fourth of $L$, not passing over hinge line, occasionally with spines; $S_{1}$ quite deep, oriented backwards, base at $27-30 \%$ of $H$ and $36-38 \%$ of $L ; L_{2}$ always distinct, vertical and narrow, axis at $42-45 \%$ of $L ; S_{2}$ narrow, vertical, base located high (26$30 \%$ of $\mathrm{H}$ ); $\mathrm{L}_{3}$ bulbous, rounded, large (diameter $37-39 \%$ of $\mathrm{L}$ ), highest part just at hinge line (quite not overpassing), covered with spines which can be long; spines are also distributed on the surface of the valves and on free margins of PB; ventral lobe poorly developed. Dorsal view: diamond-like carapace outline, hinge line straight.

Early ontogenetic stages: ACA very obtuse; maximum of convexity of AB located above mid $\mathrm{H}$; $S_{3}$ and $L_{4}$ invisible; the free margins are covered with several rows of isolated spines. When the specimens reach $790-800 \mu \mathrm{m}$, the space between velar spines is progressively calcified, calcification forming a continuous velum. Carapace outline in dorsal view biconvex with maximum width at mid $\mathrm{L}$.

Late ontogenetic stages and adults $(L>750 \mu \mathrm{m}$ and $\mathrm{H}>550 \mu \mathrm{m})$ : $A B$ with large radius of curvature with maximum of curvature at $51-58 \%$ of $\mathrm{H} ; \mathrm{S}_{3}$ and $\mathrm{L}_{4}$ visible in most specimens. The velate structure is a large smooth velum which begins a little below ACA. Some spines could be present just at the anterior end of the velum. VB is largely rounded and bordered by the velum which decreases and disappears at the junction with PB where it is replaced by spines; maximum of curvature of VB is located at $33-38 \%$ of $L$; velum relatively broad comprising $17-$ $23 \%$ of $\mathrm{H}$; PB with large radius of curvature with maximal convexity located at $25-29 \%$ of $\mathrm{H}, \mathrm{PB}$ covered by numerous spines; PCA $105-110^{\circ}$; carapace outline in ventral view diamond-like with large antrum space anteriorly, right and left velums distinct at $A B$, posterior part of $A B$ covered by spines; maximum width located at the posterior third of $\mathrm{L}$. 
Sexual dimorphism appears during ontogeny before the adult stage (and sexual maturity), as observed in material from North Iran (Forel et al. 2015). This dimorphism is characterized by the larger PB radius of curvature and the greater posterior carapace thickness at the females. Dimensions. $\mathrm{L}=426-1130 \mu \mathrm{m} ; \mathrm{H}=282-807 \mu \mathrm{m} ; \mathrm{W}=419-488 \mu \mathrm{m}$ (fig. 3).

Remarks. Hollinella (Hollinella) lungcamensis sp. nov. is very similar to H. ulrichi (Knight, 1928) from the Late Carboniferous - Early Permian of the South-Central United States, Wales, the Netherlands, Belgium and Germany (see complete synthesis on H. ulrichi (Knight, 1928) in Bless \& Jordan 1972). The two species have the same ornamentation at the free margin and the same ontogenetic variability and sexual dimorphism. The main difference is the fusion of $L_{1}$ and $L_{2}$ and the spines which are more irregularly distributed the ventral margin of $H$. ulrichi.

H. spinulosa Demanet, 1949 from the Late Carboniferous of Southern Limburg, the Netherlands and Campine Basin of Belgium (see synthesis in Bless \& Jordan 1972) shows less and wider arranged spines on the free margins and a reticulate carapace surface. H. echinata Hao, 1993 from the Changhsingian (Late Permian) of Guizhou, South China has the same lobes, the same spines as $H$. lungcamensis sp. nov., but its velum runs from ACA to PCA and the $\mathrm{H} / \mathrm{L}$ ratio is lower.

H. panxiensis Wang, 1978 from the Wuchiapingian (Late Permian)- Induan (Early Triassic) of South China has a complete velum extending from ACA to PCA, a distinct ventral lobe and flattened cardinal angles.

H. magninoda Wang, 1978 from the Wuchiapingian - Induan of South China has long spines at ACA and PCA and a broad velum (1/3 of $H)$.

The new species is attributed to the subgenus Hollinella (Hollinella) in regard of the clearly identified $L_{2}$, the velum which ended at the lower part of BP and the presence of a row of ventral spines in larval stages (see fig. 6).

\section{Hollinella from the South China Block}

Hollinella tingi has also been reported, but not illustrated, from marginal marine environments of the so-called Permian-Triassic Transition Beds and the overlying Lower Triassic Kayitou Formation of Yunnan (Mide section) and Guizhou (Tucheng section), South China (e.g., Yu et al. 2010). Recent fieldwork enabled the second author to collect abundant Hollinella specimens from the lowermost Kayitou Formation of the Mide section (preliminary analysis in 
Bercovici et al. 2015). These specimens are mostly preserved as moulds on the surface of cracked siltstone/fine sandstone. Abundant specimens occur with the two valves still attached dorsally in a butterfly shape indicating very quiet hydrodynamic conditions at the time of deposition and rapid burial. Although extremely abundant, these Hollinella specimens are poorly preserved and corroded so that the original surface structure is usually not observable. Despite poor preservation, all observed specimens could correspond to Hollinella panxiensis described above. The size range of all specimens of this assemblage suggests that several ontogenetic stages are present. The individual stages can, however, hardly be differentiated because specimens cannot be extracted from the matrix and are often only partially exposed. Sexual dimorphism is clearly visible in the Hollinella specimens from Mide.

No ostracods have been found so far in the underlying Late Permian Xuanwei Formation in the Mide section. The monospecific assemblage of Hollinella panxiensis from this very marginal marine succession seems to result from a short proliferation event during unstable conditions.

\section{Conclusion}

Hollinella tingi (Patte, 1935) does not occur in the latest Permian - Early Triassic. Three Hollinella species are recognized in the latest Permian - earliest Triassic and assigned to Hollinella panxiensis Wang, 1978, Hollinella magninoda Wang, 1978 and Hollinella (H.) lungcamensis sp. nov. The first two species have quite a long stratigraphic range extending from the Wuchiapingian to the Griesbachian. $H$. (H.) lungcamensis, for the time being, is only present in the Hong Ngai Formation in Vietnam, which is of topmost Changhsingian and earliest Induan (H. parvus zone) age. H. (H.) lungcamensis is characteristic for the postextinction period. In the Lung Cam section, $H$. $(H$.) lungcamensis is associated with many other palaeocopid and podocopid ostracod taxa (work in progress) and with foraminifers of the genera Geinitzina, Nodosaria, Globivalvulina, the species Hyperammina deformis, Ammodiscus kalhori, and microconchids (Nestell et al. 2015). The detailed geochemical analysis of foraminiferal tests and pyrite clusters led Nestell et al. (2015) to evoke euxinic conditions at the seabed and a carbon-enriched sea-water column. The source of the carbon could have been global coal fly ash or forest fire-dispersed charcoal, or a combination of both, 
353 which accumulated in the Palaeo-Tethys Ocean. The presence of benthic ostracods in the 354 same samples, however, indicates that the bottom water could not be anoxic nor dysoxic. The 355 analysis of the total ostracod assemblages will improve these ecological data.

358 Acknowledgments:

359 The authors thank Mark Williams (University of Leicester, UK), anonymous reviewer and the editors 360 for their constructive comments and corrections on the first version of the manuscript. We thank 361 Justine Jacquot and Charlène Letenneur (CR2P - MNHN) for drawing of figures 6 and 7 and Alexandre 362 Lethiers (CR2P - UPMC) for the production of figure 5. Y.A. is supported by the Chinese projects number 363 B08030 (111 Project), 41572001 and 41430101 (NFSC Project). 


\section{REFERENCES}

Bercovici, A., Cui, Y., Forel, M.B., Yu, J.X. \& Vajda, V. 2015. Terrestrial paleoenvironment characterization across the Permian-Triassic boundary in South China. Journal of Asian Earth Sciences, 98, 225-246.

Bless, M. J. M. 1970. On a case of dimorphism in the last juvenile stage of a hollinid ostracode from the Namurian B-C of the La Camocha Mine (Gijon, N. Spain). Breviora Geologia Asturica, 13, 31-38.

Bless, M. J. M. \& Jordan, H. 1971. Classification of Palaeocopid ostracodes belonging to the families Ctenoloculinidae, Hollinidae and Hollinellidae. In H. J. Oertli (Ed.), Paléoecologie des ostracodes. Colloque de Pau 1970. Bulletin Centre de Recherche Pau-SNPA, 5 suppl., 869-890.

Bless, M. J. M. \& Jordan, H. 1972. Ostracodes of the Family Hollinellidae. Mededelingen Rijks Geologische Dienst, 3(1), 1-155.

Bless, M. J. M., Jordan, H. \& Michel, M. P. 1969. Ostracodes from the Aegir Marine Band (basis Westphalian C) of South Limburg (The Netherlands). Mededelingen Rijks Geologische Dienst, 20, 19-49.

Coryell, H. N. 1928. Some new Pennsylvanian Ostracoda. Journal of Paleontology, 2, 377-381. Crasquin, S. \& Forel, M.-B. 2013. Ostracods (Crustacea) through Permian-Triassic events. Earth Science Reviews, 137, 52-64.

Crasquin, S., Forel, M.-B., Feng, Q., Yuan, A., Baudin, F. \& Collin, P. Y. 2010. Ostracods (Crustacea) through Permian-Triassic boundary in South China: the Meishan stratotype (Zhejiang Province). Journal of Systematic Palaeontology, 8(3), 331-370.

Crasquin-Soleau, S., Marcoux, J., Angiolini, L., Nicora, A. \& Bertho, Y. 2004. A new ostracod fauna from Permian - Triassic boundary in Turkey (Taurus, Antalya Nappes). Micropaleontology, 50(3), 281-295.

Demanet, F. 1949. Contribution à l'étude de la microfaune marine du Westphalien de la Campine. Bulletin de I'Institut Royal des Sciences Naturelles de Belgique, 25, 1-16.

Forel, M.-B. \& Crasquin, S. 2011. Lower Triassic ostracods (Crustacea) from Meishan section, Permian-Triassic GSSP (Zhejiang Province, South China). Journal of Systematic Palaeontology, 9(3), 455-466.

Forel, M. B., Crasquin, S., Chitnarin, A., Angiolini, L. \& Gaetani, M. 2015. Precocious sexual 
dimorphism and Lilliput effect of ostracods (Crustacea) through the Permian - Triassic events in Neo-Tethys. Palaeontology, 58(3), 409-454.

Hao, W. 1992a. Early Triassic ostracods from Guizhou. Acta Micropalaeontologica Sinica, 9, 37-44. [in Chinese with English abstract].

Hao, W. 1992b. Latest Permian Ostracods from Zhenfeng, Guizhou. Acta Scientiarum Naturalium, Universitatis Pekinensis, 28(2), 236-249. [in Chinese with English abstract].

Hao, W. 1993. Latest Permian Ostracoda from Zunyi, Guizhou. Acta Scientiarum Naturalium, Universitatis Pekinensis, 29(2), 249-256. [in Chinese with English abstract].

Hao, W. 1994. The development of the Late Permian - Early Triassic ostracod fauna in Guizhou Province. Geological Review, 40(1), 87-93. [in Chinese with English abstract].

Hao, W. 1996. Ostracods from the Upper Permian and Lower Triassic of the Zhenfeng section, South China. Journal of Geosciences, Osaka City University, 39(2), 19-27. [in Chinese with English abstract].

Hennignsmoen, G. 1953. Classification of Paleozoic straight hinged Ostracoda. Norsk Geologisk Tidsskrift, 31, 185-288.

Henninsgmoen, G. 1965. On certain features of Palaeocope Ostracodes. Geologiska Föreningens I Stockholm Förhandlingar, 86, 329-394.

Horne, D. J., Cohen, A. \& Martens, K. 2002. Taxonomy, Morphology and Biology of Quaternary and living Ostracoda. In J. A. Holmes \& A. Chivas (Eds.), The Ostracoda: applications in Quaternary Research: Geophysical Monograph, 131, pp. 5-36.

Hornibrook, N. B. H. 1949. A new family of living ostracods with striking resemblances to some Palaeozoic Beyrichiidae. Transactions of the Royal Society of New Zealand, 77, 469-471.

Hornibrook, N. B. H. 1963. The New Zealand ostracode family Punciidae. Micropaleontology, 9(3), 318-320.

Hou, Y. T. 1954. Some Lower Permian ostracods from Western Hupeh. Acta Palaeontologica Sinica, 2(2), 227-266. [in Chinese with English abstract].

Ishizaki, K. 1964. On some Carboniferous Ostracod genera from Japan. Saito Ho-on Kai Museum Research Bulletin, 33, 30-40.

Jaanusson, V. 1957. Middle Ordovician ostracodes of Central and Southern Sweden. Geological Institute University Uppsala Bulletin, 37, 176-442.

Jiang, Z. 1983 in Wei, M., Li, Y., Jiang, Z. \& Xie, L. 1983. Palaeontological Atlas of Southwest China. Volume of microfossils: subclass Ostracoda. Beijing: Geological Publishing House 
Beijing, China, 254 pp. [in Chinese with English abstract].

Kellett, B. 1929. The Ostracode genus Hollinella, expansion of the genus and description of some Carboniferous species. Journal of Paleontology, 3, 196-217.

Kesling, R. V. 1969. Copulatory adaptations in ostracods. Part III. Adaptations in some extinct ostracods. Contributions from the Museum of Paleontology. The university of Michigan, 22(21), 273-312.

Knight, J. B. 1928. Some Pennsylvanian Ostracodes from the Henrietta Formation of Eastern Missouri (part 1). Journal of Paleontology, 3, 229-267.

Kozur, H. 1985. Neue Ostracoden - Arten aus dem Oberen Mittelkarbon (Höheres Moskovian), Mittel- und Oberperm des Bükk- gebirges (N- Ungarn). Geologish Paläontologische Mitteilungen Innsbruck, 2, 1-145.

Latreille, P. A. 1806. Genera crustaceorum et insectorum: secundum ordinem naturalem in familias disposita, iconibus exemplisque plurimis explicate. Tomus 1., A. Koenig, Paris, $303 \mathrm{pp}$.

Martin, J. W. \& Davis, G. E. 2001. An updated classification of Crustacea. Natural History Museum of Los Angeles County. Science Series 39, 1-139.

Nestell, G. P., Nestell, M. K., Ellwood, B. B., Wardlaw, B. R., Basu, A. R., Ghosh, N., Lane, L. T. P., Rowe, H. D., Hunt, A., Tomkin, J. H. \& Ratcliffe, K. T. 2015. High influx of carbon in walls of agglutinated foraminifers during the Permian-Triassic transition in global oceans. International Geology Review, 57 (4), 411-427.

Patte, E. 1935. Fossiles paléozoïques et mésozoïques du Sud Ouest de la Chine. Paleontologica Sinica Serie B, 15(2), 1-50.

Sars, G. O. 1866. Oversigt af marine Ostracoder. Norske Videnskaps-Akademi, Förhandlingar $1865,1-130$.

Scott, H. W. 1961. Suborder Beyrichicopina Scott, n.suborder in R. C. Moore (ed.) Treatise of Invertebrate Paleontology. Part Q. Arthropoda 3, Crustacea, Ostracoda: Geological Society of America and University of Kansas Press, Q111.

Scott, H. W. \& Wainwright, J. 1961. Dimorphism of Ostracoda in R. C. Moore (ed.) Treatise of Invertebrate Paleontology - Part Q Arthropoda 3, Crustacea, Ostracoda. Lawrence, Texas: The University of Kansas Press, Q37-Q43.

Shi, C. G. \& Chen, D. Q. (1987). The Changhsingian ostracodes from Meishan Changxing, Zhejiang. In: Nanjing Institute of Geology and Palaeontology (Ed.), Stratigraphy and 
Palaeontology of Systemic Boundaries in China; Permian and Triassic Boundary Nanjing: Nanjing University Press, 5, pp. 23-80). [in Chinese with English abstract].

Sohn, I. G. 1950. Growth series of Ostracodes from the Permian of Texas. United States Geoleological Survey Professional Paper, 221-C, 33-43.

Son, T. H., Koeberl, C., Ngoc, N. L. \& Huyen, D. T. 2007. The Permian-Triassic boundary sections in northern Vietnam (Nhi Tao and Lung Cam sections): Carbon-isotope excursion and elemental variations indicate major anoxic event. Palaeoworld, 16, 51-66.

Swartz, F. M. 1936. Revision of the Primitiidae and Beyrichidae with new ostracoda from the Lower Devonian of Pennsylvania. Journal of Paleontology, 10, 541-586.

Van Veen, J. E. 1922. The identity of the genera Poloniella and Kloedenella. Royal Academy Amsterdam, 23, 993-996.

Wang, S. 1978. Late Permian and Early Triassic ostracods of Western Guizhou and Northeastern Yunnan. Acta Palaeontologica Sinica, 17(3), 277-308. [in Chinese with English abstract].

Wardlaw B. R., Nestell M. K., Nestell G. P., Ellwood B. B. \& Phuong Lan, L. T. 2015. Conodont biostratigraphy of the Permian - Triassic boundary sequence at Lung Cam, Vietnam. Micropaleontology, 61 (4-5), 313-334.

Watabe, K. \& Kaesler, R. L. 2004. Ontogeny of a new species of Paraparchites (Ostracoda) from the Lower Permian Speiser Shale in Kansas. Journal of Paleontology, 78(3), 603611.

Wei, M. 1981. Early and Middle Triassic Ostracods from Sichuan. Acta Palaeontologica Sinica, 20(6), 501-510. [in Chinese with English abstract].

Yu, J.X., Broutin, J., Huang, Qi-Sheng \& Grauvogel-Stamm, L. 2010. Annalepis, a pioneering lycopsid genus in the recovery of the Triassic land flora in South China. Comptes Rendus Palevol, 9, 479-486. 
Legend of figures

488

489

490

491

492

493

494

495

496

497

498

499

500

501

502

503

504

505

506

507

508

509

510

511

512

513

514

515

516

517

Figure 1: Location map and stratigraphic column of the Lung Cam section in Northern Vietnam with sample numbers (log modified after Nestell et al. 2015).

Figure 2: Interpretative drawing of some specimens of Hollinella (H.) lungcamensis sp. nov.

A, B, C: adults with well-developed velum as adventral structure; A: female in left lateral view;

B: male in left lateral view; C: male in right lateral view; D, E, F: juveniles with spines as adventral structures; D and $\mathrm{F}$ in left lateral view and $\mathrm{E}$ in right lateral view. Scale bar is $100 \mu \mathrm{m}$.

Figure 3: Height/length diagram of Hollinella (H.) lungcamensis sp. nov. from Vietnam with indication of individual samples.

Figure 4: Height/length diagram of Hollinella (H.) lungcamensis sp.nov. with indication of specimens with velum or spines on free margins and indication of identified males and females.

Figure 5: Specimens of Hollinella (H.) lungcamensis sp. nov. from the latest Permian earliest Triassic of the Lung Cam section, Northern Vietnam. All the specimens are at the same scale and scale bar is $200 \mu \mathrm{m}$. When possible, the gender of specimen is indicated. The numbers with the prefix P6M correspond to the collection numbers of Pierre et Marie Curie University (Paris) Micropalaeontology collection.

A, paratype, left lateral external view of a left valve,,+ P6M3776; B, left lateral external view of a left valve, $\sigma^{*}, \mathrm{P} 6 \mathrm{M} 3778 ; \mathbf{C}$, holotype, right lateral external view of a right valve, $\sigma^{\prime}$, P6M3775; D, right lateral external view of a right valve, o', P6M3779; E, paratype, left lateral external view of a left valve,,+ P6M3777; F, left lateral external view of a left valve, $q$, P6M3780; G, left lateral external view of a left valve, $\$, P 6 M 3781 ; \mathbf{H}$, right lateral external view of a complete carapace, $9, \mathrm{P} 6 \mathrm{M} 3782 ; \mathrm{I}$, right lateral external view of a complete carapace, P6M3783; J, left lateral external view of a left valve, P6M3784; K, right lateral external view of a right valve, P6M3785; L, right lateral external view of a complete carapace, 9, P6M3786; $\mathbf{M}$, 
left lateral external view of a complete carapace, $0^{n}, \mathrm{P} 6 \mathrm{M} 3787 ; \mathbf{N}$, right lateral external view of a right valve,,$+ \mathrm{P} 6 \mathrm{M} 3788 ; \mathbf{0}$, left lateral external view of a complete carapace, P6M3789; P, right lateral external view of a complete carapace, P6M3790; Q, left lateral external view of a left valve, P6M3791; $\mathbf{R}$, left lateral external view of a left valve, P6M3792; S, left lateral external view of a complete carapace, P6M3793; T, right lateral external view of a complete carapace, P6M3794; U, left lateral external view of a left valve, P6M3795; V, left lateral external view of a left valve, P6M3796; W, right lateral external view of a complete carapace, P6M3797; X; left lateral external view of a complete carapace, P6M3798; Y, right lateral external view of a complete carapace, P6M3799; $\mathbf{Z}$, left lateral external view of a complete carapace, P6M3800; A', left lateral external view of a complete carapace, P6M3801; B', right lateral external view of a complete carapace, P6M3802; $\mathbf{C}^{\prime}$, dorsal external view of a complete carapace, P6M3803; D', ventral external view of a juvenile complete carapace, P6M3804; E'; ventral external view of a complete carapace, $\sigma^{\prime \prime}, \mathrm{P} 6 \mathrm{M} 3805 ; \mathbf{F}^{\prime}$, ventral external view of a

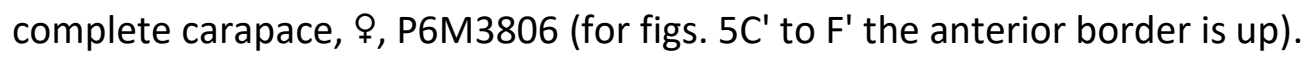

Figure 6: Schematic representation of ontogenetic variations in some genera and subgenera of Hollinellidae (modified after Bless \& Jordan 1970).

Figure 7: Schematic representation of Hollinella (Hollinella) lungcamensis sp. nov. with descriptive terms and abbreviations used in text. The small arrows indicate the anterior part of the carapace.

A. external view of right valve: $S_{1}, S_{2}, S_{3}$ : sulcus from anterior to posterior; $L_{1}, L_{2}, L_{3}, L_{4}$ : lobes from anterior to posterior; L: maximum length of carapace; $\mathrm{H}$ : maximum height of carapace; small dots indicate the location of maximum of convexity of $A B, P B$ and $V B$.

B. external view of right valve: $A B$ : anterior border, PB: posterior border; $D B$ : dorsal border; VB: ventral border; ACA: anterior cardinal angle; PCA: posterior cardinal angle.
C. Ventral view; W: maximum width of carapace.

D. Dorsal view: $L_{1}$ to $L_{3}$ and $S_{1}$ to $S_{3}$, lobes and sulcus same as $A$. 

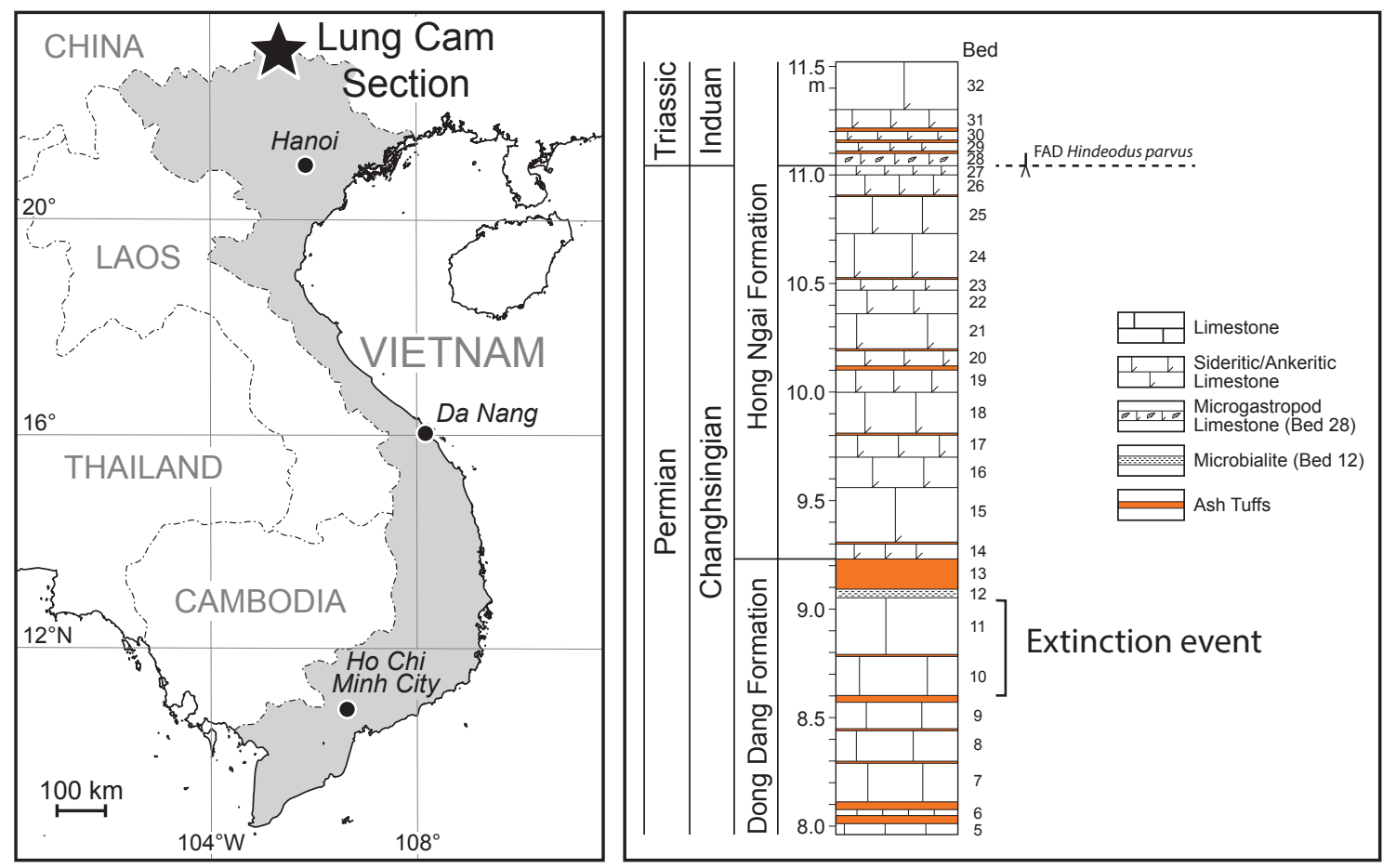

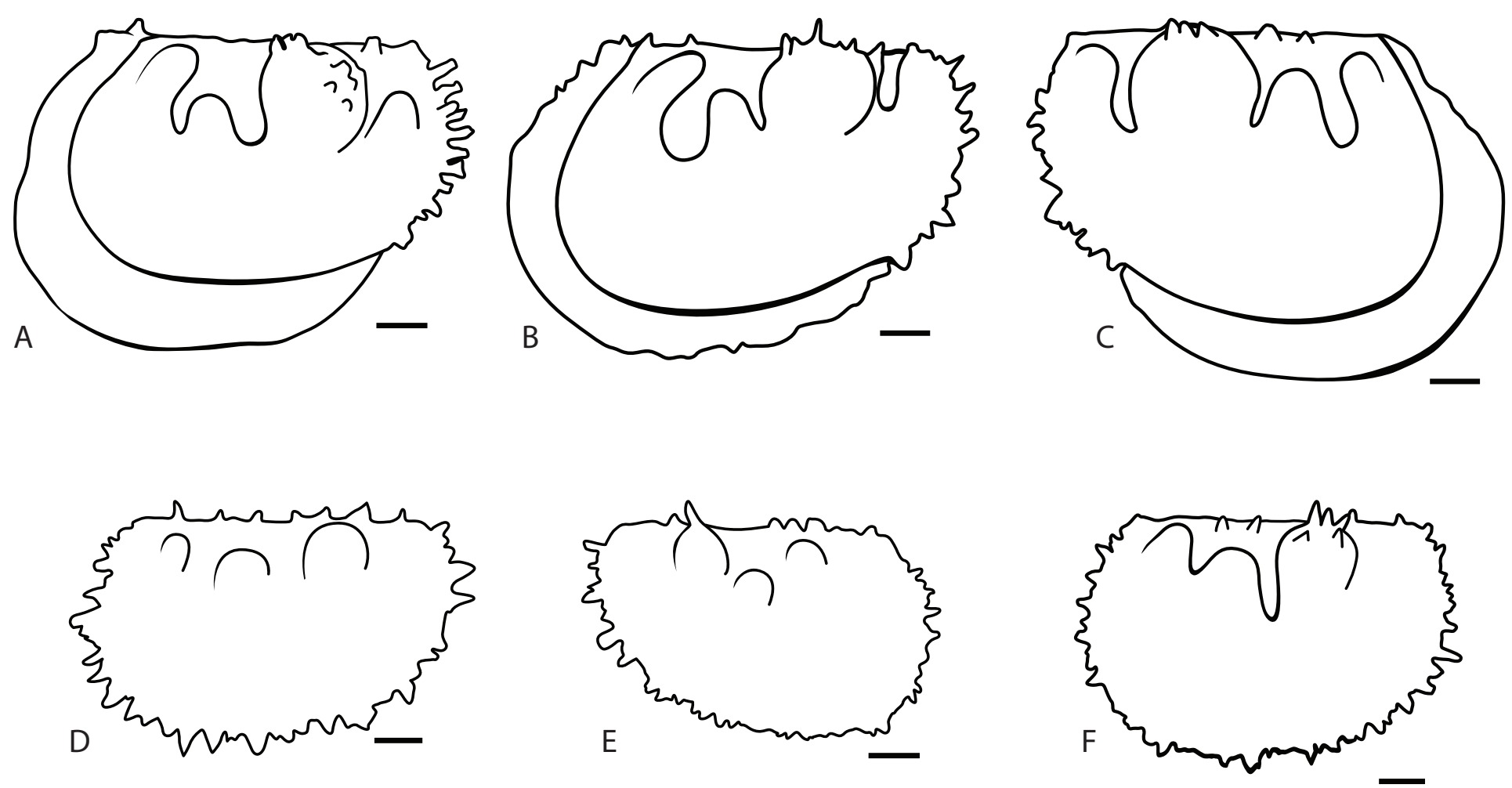


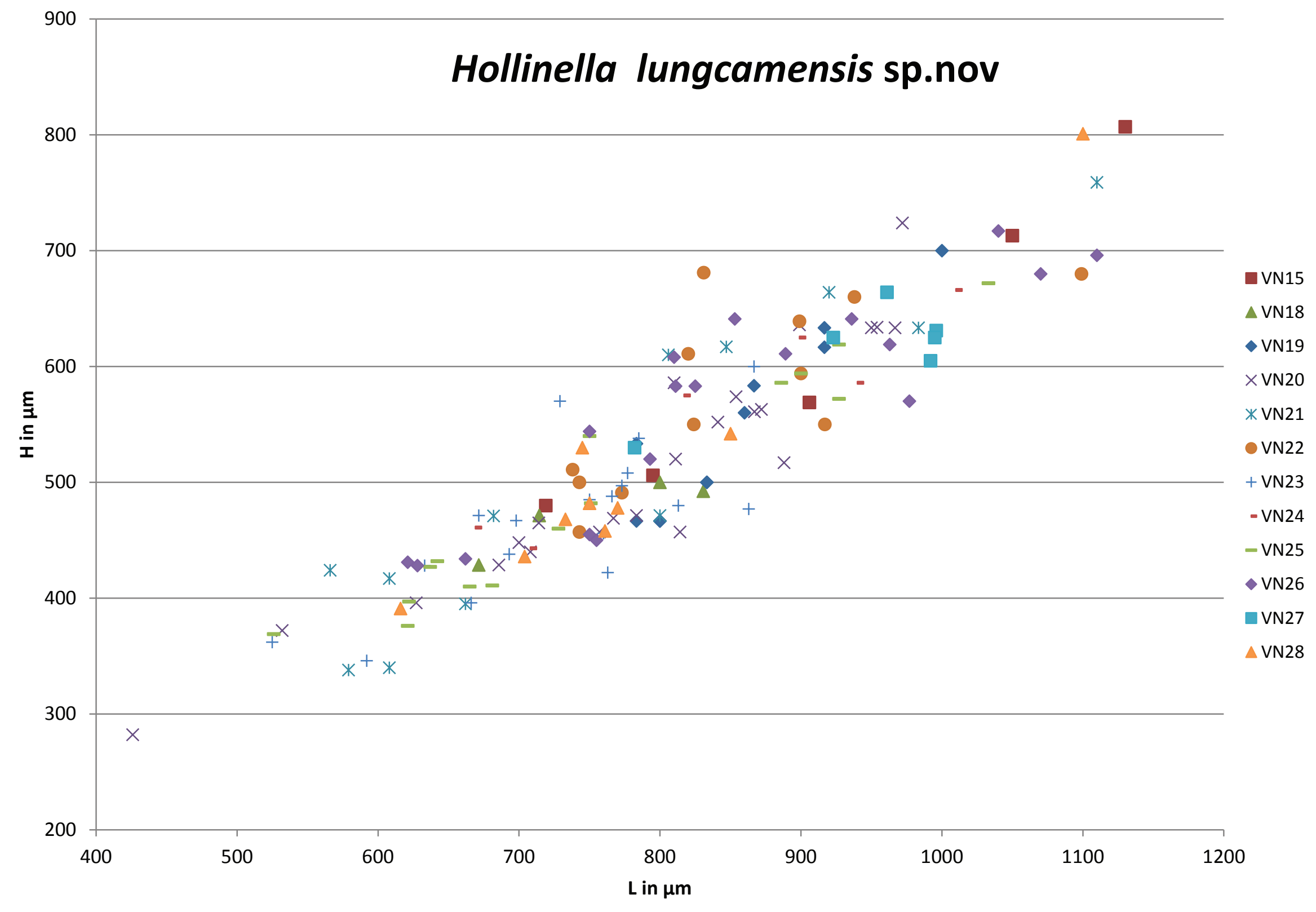




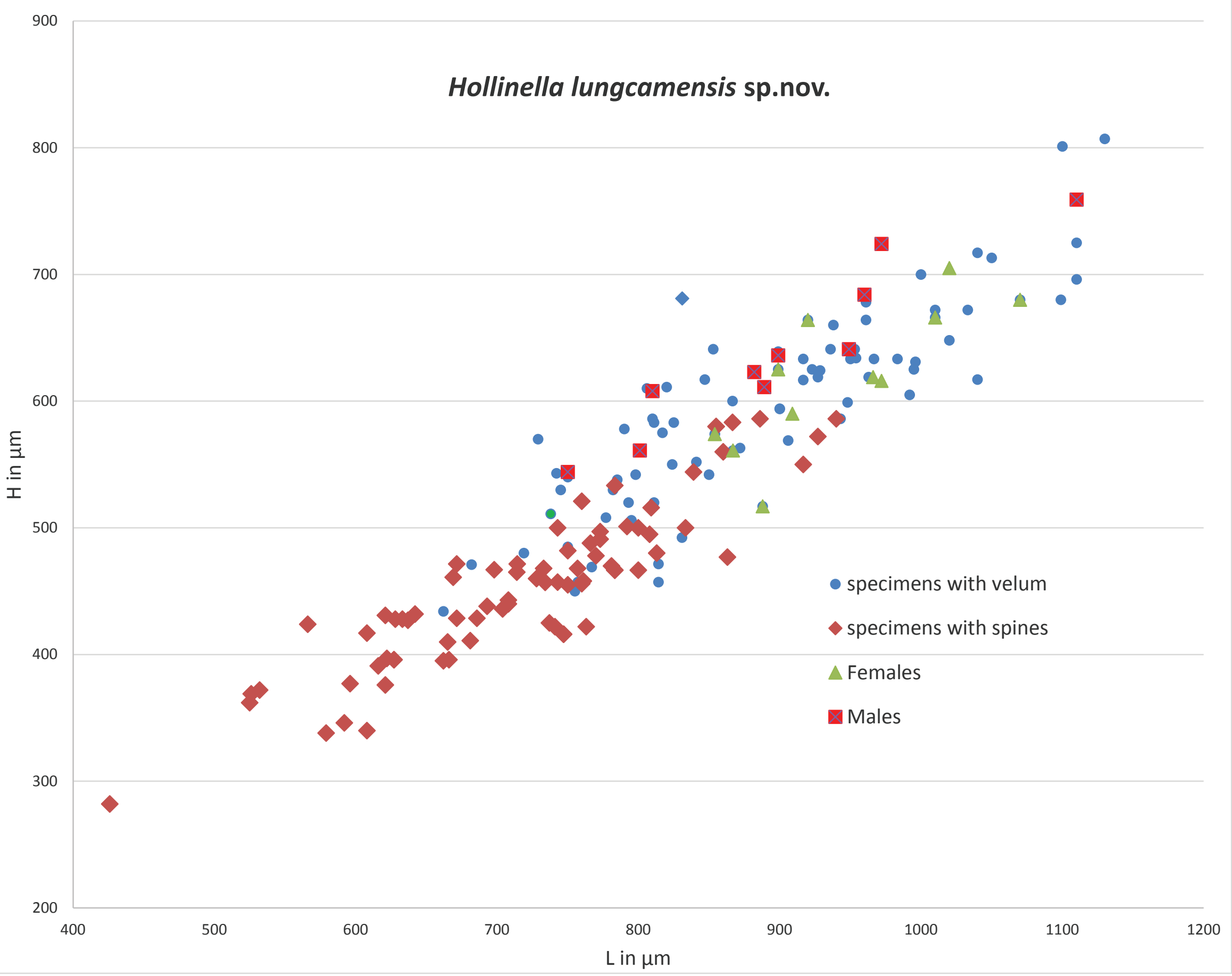




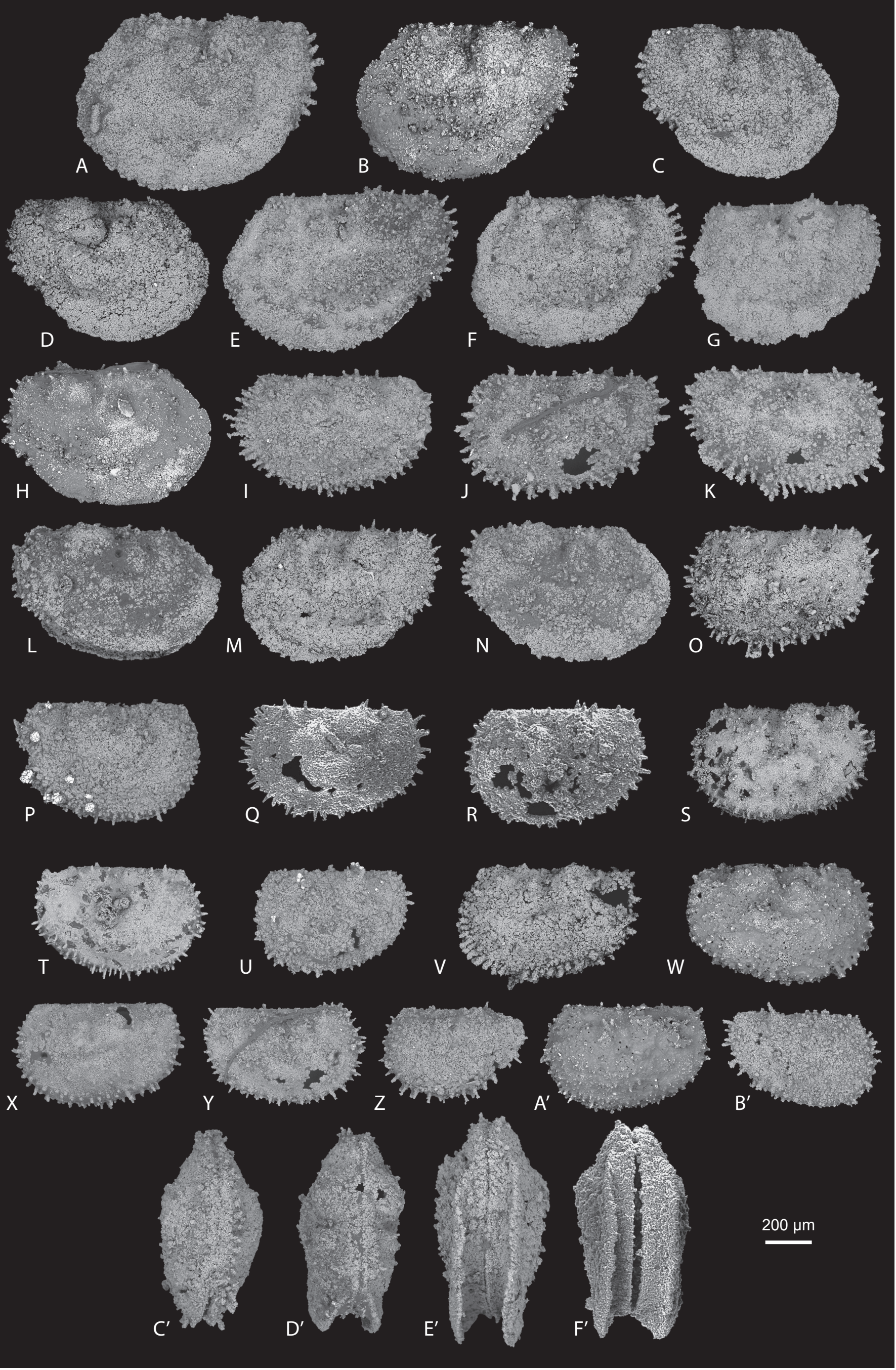




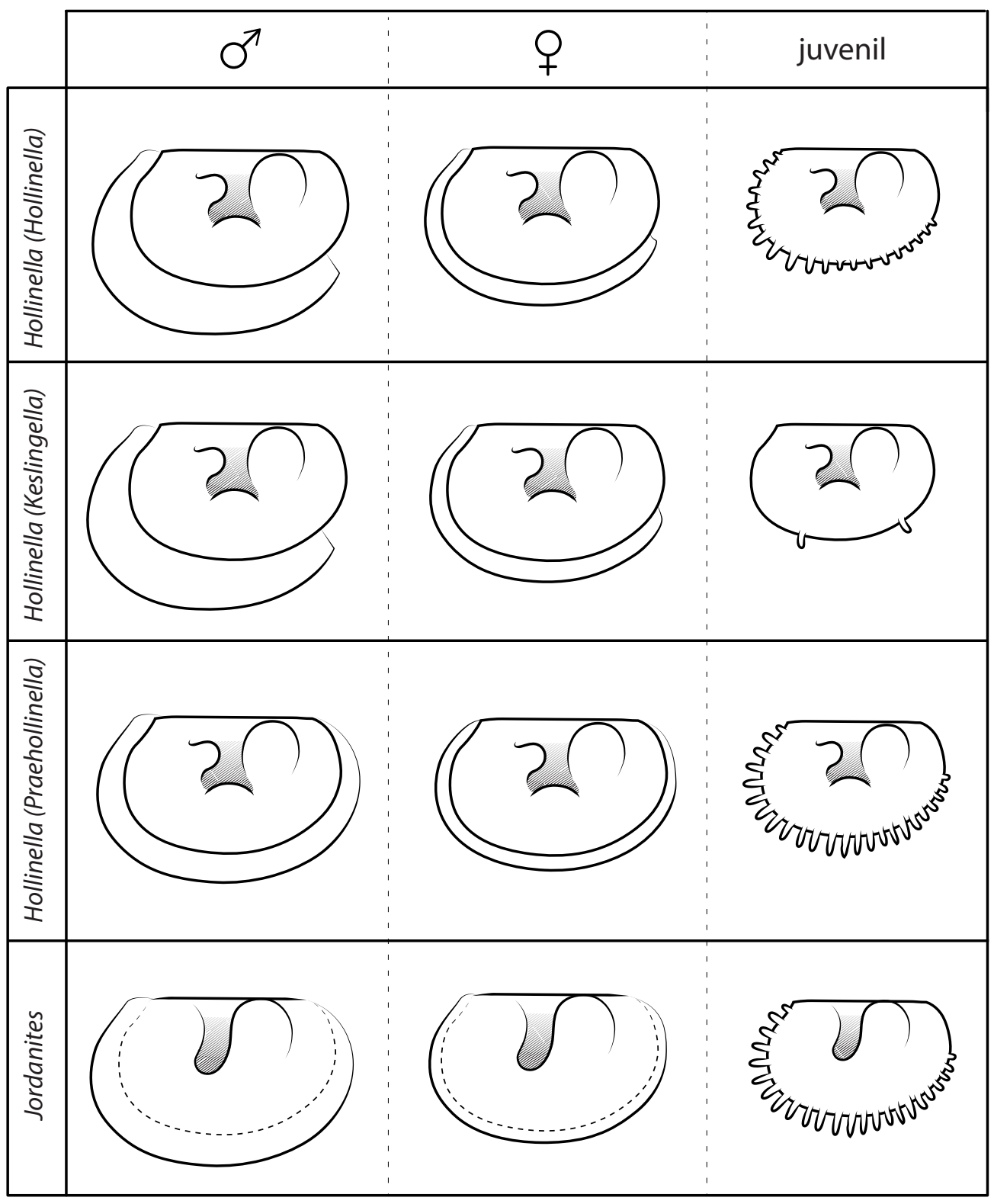



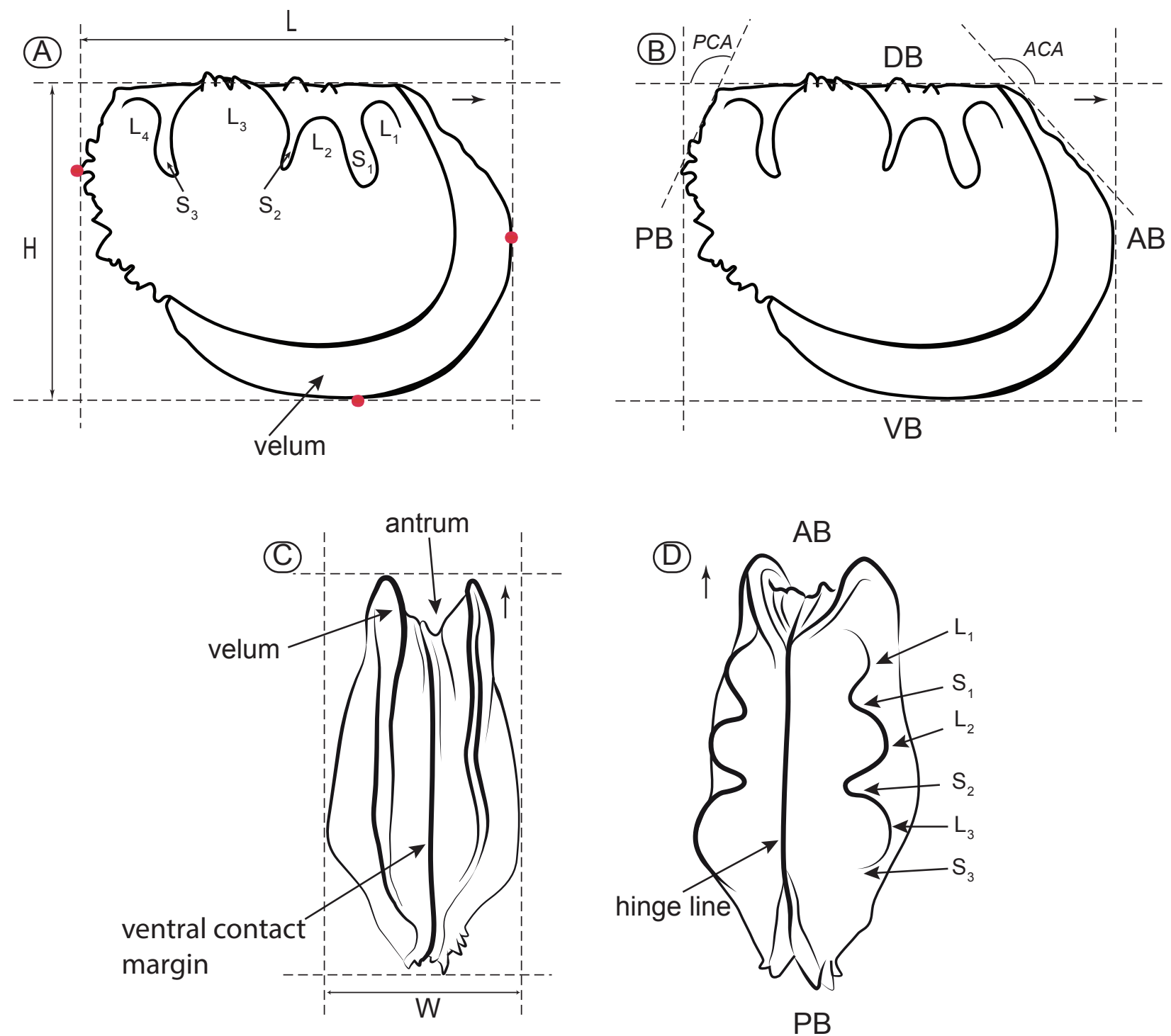